
\title{
28 Research Square \\ The Effects of Physical Running on Dendritic Spines and Amyloid-Beta Pathology in 3xTg-AD Male Mice
}

\section{Benke Xu}

Yangtze University

Yun He

Yangtze University

Lian Liu

Yangtze University

Guosheng Ye

Guangzhou Medical University

\section{Lulu Chen}

Guangzhou Medical University

\section{Qingning Wang}

Guangzhou Medical University

\section{Michael Chen}

University of California Los Angeles

\section{Yuncai Chen ( $\nabla$ yuncaic@uci.edu )}

University of California Irvine https://orcid.org/0000-0002-4862-3704

\section{Dahong Long}

Guangzhou Medical University

\section{Research}

Keywords: Alzheimer's disease, dendritic spines, synapses, amyloid, memory, physical training, hippocampus.

Posted Date: October 8th, 2021

DOl: https://doi.org/10.21203/rs.3.rs-957519/v1

License: (1) (i) This work is licensed under a Creative Commons Attribution 4.0 International License. Read Full License 
The effects of physical running on dendritic spines and amyloid-beta pathology in 3xTg-AD male mice

Benke $\mathrm{Xu}^{1, \#}$, Yun $\mathrm{He}^{1, \#}$, Lian Liu², Guosheng Ye ${ }^{3}$, Lulu Chen ${ }^{3}$, Qingning Wang ${ }^{3}$, Michael Chen ${ }^{4}$, Yuncai Chen $^{5, *}$, Dahong Long ${ }^{3, *}$

${ }^{1}$ Department of Human Anatomy, School of Basic Medical Sciences, Yangtze University, Hubei 434023, China;

${ }^{2}$ Department of Pharmacology, School of Basic Medical Sciences, Yangtze University, Hubei 434023, China;

${ }^{3}$ Key Lab of Neuroscience, School of Basic Medical Sciences, Guangzhou Medical University, Guangzhou 511436, China;

${ }^{4}$ University of California, Los Angeles, CA 90095, USA;

${ }^{5}$ Department of Pediatrics, University of California, Irvine, CA 92697, USA.

\# These authors contributed equally to this work.

Running title: Prolonged running reduces $A \beta$ and benefits synaptic structure and spatial memory

\section{*Corresponding authors:}

Dahong Long, PhD

Key Lab of Neuroscience, School of Basic Medical Sciences

Guangzhou Medical University

Guangzhou 511436, China

Tel: (+86) 0203710 3202; Fax: (+86) 02037103202

E-mail: longdahong88@qq.com

or

Yuncai Chen, $\mathrm{PhD}$

Department of Pediatrics

University of California-Irvine, Irvine

California 92697, USA

E-mail: yuncaic@uci.edu

Number of figures: 5

Number of words: Abstract $=237$, Background $=735$, Results $=1,729$, Discussion $=1,565$.

Total characters (no spaces): 59,511 


\begin{abstract}
Background: Memory loss is the key symptom of Alzheimer's disease (AD). As successful drug treatments have not yet been identified, non-pharmaceutical intervention, such as physical exercise has been recognized as an effective strategy to improve memory function of people with dementia. Here we investigated the effect of prolonged physical running on hippocampal-dependent spatial memory and underlying mechanisms in 3xTg-AD mouse, a well-established rodent model of Alzheimer's disease (AD).

Methods: 3xTg-AD transgenic mice with three AD mutations were used and compared with non-transgenic mice. Voluntary wheel running continued for 5 months ( 1 hour per day, 5 days per week) and was followed by spatial memory testing. At the end of behavior testing, dendritic spines, synapses, and synaptic proteins as well as amyloid-beta $(A \beta)$ pathology were analyzed in the dorsal hippocampi.

Results: Running improved hippocampal-dependent spatial memory in 3xTg-AD mice. This running strategy prevented both thin and mushroom-type spines on CA1 pyramidal cells in 3xTg-AD mice, whereas the effects of running in non-transgenic mice were limited to thin spines. The enormous effects of running on spines were accompanied by increased synapses and higher expressions of synaptic proteins. Notably, running downregulated the processing of amyloid precursor protein, resulting in reduced $A \beta$ peptides, and spatial memory performance correlated with levels of $A \beta$ peptides $A \beta_{1-40}$ and $A \beta_{1-42 .}$.
\end{abstract}

Conclusion: These data suggest that prolonged running may improve memory in preclinical AD via slowing down amyloid pathology and preventing loss of synaptic contacts.

Keywords: Alzheimer's disease, dendritic spines, synapses, amyloid, memory, physical training, hippocampus. 


\section{Background}

The progressive loss of memory in patients with Alzheimer's disease (AD) is accompanied by several primary pathological features including extensive loss of synaptic connections and abnormal deposits of amyloid plaques in the brain [1, 2]. AD is categorized into early-onset and late-onset two forms (familial $A D$ and sporadic $A D$, respectively), and the later accounts for more than $98 \%$ of $A D$ cases. Whereas the cause of $A D$ is not yet fully understood, it is generally believed that the early-onset Alzheimer's is a result of genetic mutation in one of three genes that are amyloid precursor protein (APP), presenilin-1 (PSEN1), and presenilin-2 (PSEN2), and the late-onset Alzheimer's arises from a combination of genetic, environmental, and lifestyle factors [1, 3]. Despite current intensive research, successful drug treatments have yet to be identified. Because AD is complex and the actual underlying cause of this disease is poorly defined [1, 2 , $4,5,6]$, non-pharmaceutical interventions that may help reduce the risk of cognitive decline and delay the onset of $A D$ are worthy of attention.

Physical exercise is a simple intervention that remarkably benefits cognition and has been recognized as an effective strategy to improve learning and memory functions of aged people with or without cognitive decline $[7,8,9,10,11,12,13,14,15]$. Although it is not certain yet whether exercise can alleviate and/or delay memory deficits in patients who have been diagnosed with $A D$ [16], data from clinical trials have shown that regular and moderate physical exercise and training have beneficial effects on dementia patients, particularly those with mild dementia $[12,14,17,18,19]$. It should be noted that the effects of physical exercise on patients with $A D$ are largely dependent on the type, frequency, and intensity of exercise applied. How does physical exercise benefit learning and memory functions and reduce the risk for dementia? An increasing body of evidence suggests that physical exercise can lead to structural and functional changes in brain regions important for learning and memory, such as the hippocampus [20, 21, $22,23,24,25]$. Studies in aged animals [26, 27, 28] and in animal models of neurodegenerative diseases [e.g., 29, 30] have shown that voluntary exercise and activity can promote neurogenesis and cell proliferation and enhance synaptic plasticity. We have reported that voluntary wheel running started at an older age of mice (16 months old) can prevent aging-related selective loss of presynaptic inputs and postsynaptic dendritic spines in the hippocampus [31, 32]. Importantly, the degree of running-provoked increase of dendritic spines, particularly those thin spines bearing small synapses, positively correlates with spatial memory performance in individual animals [31, 33], suggesting that reserved synaptic contacts contribute critically to improved memory function of these animals. The early stages of AD pathogenesis 
have been thought to occur at dendritic spines and synapses, since loss of these structures best correlates with poor memory performance [34, 35]. Furthermore, soluble oligomeric forms of amyloid-beta $(A \beta)$ and amyloid precursor protein (APP) can reduce synaptic transmission and deteriorate synapses, disrupting cognitive function $[36,37,38]$. While improved memory function via physical running has been linked to the conservation of pre- and post-synaptic contacts in normal aging mice [31,32], it is unknown whether voluntary physical running has beneficial effects on the dendritic structure and $A \beta$-pathology that is highly associated with synaptic plasticity and function in $A D$ animal models.

To explore whether voluntary exercise prevents and/or postpones AD progression, we have investigated the impacts of voluntary running on spatial memory, dendritic spines, synaptic contacts, and A $\beta$-pathology in 3xTg-AD transgenic mice, a well-established rodent model of $A D$. We have found that voluntary running for 5 months improves the spatial memory of 3xTg-AD mice measured via a novel object location task and a water maze task. When compared with $3 \times T g-A D$ sedentary mice, increased numbers of spines and synapses are apparent in area CA1 of the dorsal hippocampi of 3xTg-AD running mice, which is accompanied by a higher expression level of synaptic proteins including postsynaptic density protein-95 (PSD-95), AMPA glutamate receptor subunit GluR1, and presynaptic vesicle protein synaptophysin. Furthermore, running reduces A $\beta$-oligomers by modulation of APP processing via downregulation of BACE1 steady state levels. Particularly, the levels of $A \beta$ peptides in hippocampal CA1 correlate with spatial memory performance. Taken together, these data suggest that physical running can postpone the amyloid pathogenesis and prevent age-related loss of spines and synaptic proteins in hippocampal CA1 of 3xTgAD mice, contributing to improved spatial memory.

\section{Materials and Methods}

\section{Animals.}

Homozygous 3xTg-AD transgenic mice (3xTg-AD) containing Psen1, APPSwe, and tauP301L mutations and non-transgenic controls ( $\mathrm{Ntg}$ ) with a $\mathrm{B} 6 ; 129$ genetic background were generated from breeders purchased from the Jackson Laboratories (Bar Harbor, ME, USA). The mice were group-housed in a quiet facility and maintained on a 12-hour light/dark cycle (lights on at $7 \mathrm{am}$ ), with ad libitum access to food and water. Experiment procedures were carried out according to the National Institutes of Health Guide for Care and Use of Laboratory Animals and approved by the Bioethics Committees of the Yangtze University and Guangzhou Medical University. Male mice were subjected to a 5-month voluntary wheel running initiated 
at 8 weeks of age and compared with their age-matched sedentary controls. Two cohorts of mice were used, and each contained 3xTg-AD runner, 3xTg-AD sedentary control, Ntg runner, and Ntg sedentary control. At the end of running, one cohort of mice was subjected to a relatively 'stress-free' object location task, followed by analyses of spines and synapses, and the other was subjected to a classic water maze task, followed by measures of $A \beta$ pathology.

\section{Physical training.}

Physical training was performed as described previously [31, 32]. Briefly, mice were individually placed in vertically revolving activity wheels ( $16 \mathrm{~cm}$ in diameter and $5 \mathrm{~cm}$ in depth) and trained for 2 weeks $(6-10 \mathrm{pm})$, followed by 5 months wheel running $(7-10 \mathrm{pm})$. In the training session, mice learned to run $10 \mathrm{~min}$ on the first day, and running time progressively increased 10 min per day until they ran $1 \mathrm{~h}$ per day. After the training, mice that had learned to run voluntarily in wheels were chosen and assigned to running and sedentary groups. The mice in running group continued to run for $1 \mathrm{~h}$ per day during the dark cycle, 5 days per week. The sedentary controls were also placed in running wheels for $1 \mathrm{~h}$ per day, but the wheels were immobile. Considering the wheel running is voluntary, we set a criterion for effective training in the runners such that the heart-to-body weight ratio is at least 2 standard deviations (SD) above the mean in sedentary controls (Mean +2 SD) [31, 32]. 12 in $18 \mathrm{Ntg}$ runners and 13 in $183 x \mathrm{Tg}-\mathrm{AD}$ runners in one cohort of mice fulfilled the standard, and 10 in $16 \mathrm{Ntg}$ runners and 11 in 16 3xTg-AD runners in the other cohort were selected for data analyses.

\section{Behavioral tests of memory function.}

Object location memory test was performed as described previously [33]. Prior to training, mice were handled 2 min and then habituated to experimental apparatus for 10 min per day for 5 days in absence of objects. In training phase, two identical objects were presented for 10 min exploration. One day later, object exploration was tested for $5 \mathrm{~min}$. The training and testing were performed without knowledge of groups. A video tracking system (EthoVision, Noldus, the Netherlands) was used to record both training and testing phases. Exploration was scored when a mouse's head was oriented toward the object within $1 \mathrm{~cm}$ or when the nose was touching the object. Exploration times of object in familiar and novel locations were recorded and expressed as a ratio of novel vs. familiar. Total exploration times were calculated, and the novel/familiar ratio was used as an index of memory function. 
Water maze test was conducted with the aid of a video tracking system (EthoVision) as described [31, 32]. The maze consists of a circular tub $(120 \mathrm{~cm}$ in diameter $)$ and a transparent non-slip platform $(9 \mathrm{~cm}$ in diameter) which was placed in a constant position for each set of trials. The platform was placed in the middle of a quadrant and $1 \mathrm{~cm}$ under the surface of room temperature water. During a 5 -day training (3 trials per day), mice explored the platform and learned to associate its location to visual cues in the room. If a mouse cannot locate the platform within 60 seconds, they were gently guided to it. One day after the last trial on day 5, probe trials ( 1 min each) were performed, in which the platform was removed. During the probe testing, mice were placed in the water facing the pool wall, the number of crossing the original location of the platform and the duration of staying in the platform quadrant and all other quadrants were recorded.

\section{Tissue handling, Golgi staining, and immunohistochemistry.}

At the end of object location test, mice were anesthetized with sodium pentobarbital $(80 \mathrm{mg} / \mathrm{kg})$ and perfused via the aorta with $0.9 \%$ saline solution for 2 min to flush out blood. The brains were rapidly removed from the skull and blocked to two hemispheres. All left hemispheres were harvested for Golgi staining and right hemispheres were collected for immunohistochemistry.

Golgi staining was performed using a superGolgi kit (Bioenno Tech LLC, Santa Ana, CA). Briefly, after 2 days of impregnation in a Golgi-Cox solution $\left(22 \pm 1^{\circ} \mathrm{C}\right.$, in the dark) provided in the kit, the solution was renewed and the impregnation was continued for another 7 days $\left(22 \pm 1^{\circ} \mathrm{C}\right)$, total 9 days. The tissue blocks were sectioned coronally at $200 \mu \mathrm{m}$ (Leica VT1200). Series sections from dorsal hippocampus (1 in 3, 6-8 sections per brain, Bregma $-1.06 \mathrm{~mm}$ to $-2.54 \mathrm{~mm}$ ) were mounted on gelatin-coated slides, subjected to staining $\left(15 \mathrm{~min}, 22 \pm 1^{\circ} \mathrm{C}\right)$ and post-staining $\left(18 \mathrm{~min}, 22 \pm 1^{\circ} \mathrm{C}\right)$ in a parallel manner. Sections were dehydrated in ethanol, cleared in xylene, and covered with Permount® mounting medium.

Immunohistochemistry of postsynaptic density protein-95 (PSD-95) was performed on free-floating sections [33]. Briefly, brain tissues were fixed in $4 \%$ paraformaldehyde in $0.1 \mathrm{M}$ phosphate buffer (PB) (pH7.4) overnight at $4^{\circ} \mathrm{C}$. Fixed tissue blocks were cryoprotected in $30 \%$ sucrose in $0.1 \mathrm{M} \mathrm{PB}$ and sectioned coronally $(20 \mu \mathrm{m})$ using a Leica cryostat. Series of sections (every sixth section from dorsal hippocampus, Bregma $-1.22 \mathrm{~mm}$ to $-2.54 \mathrm{~mm}$ ) was subjected to fluorescent immunostaining. The sections were incubated with mouse monoclonal anti-PSD-95 (1:2,000, MA1-25629, clone 7E3-1B8, Affinity BioReagents, Golden, 
CO) for 3 days at $4^{\circ} \mathrm{C}$ in a parallel manner. After washing in PBS-T $(3 \times 5 \mathrm{~min})$, antibody binding was visualized with anti-mouse IgG conjugated to Alexa Fluor 488 (1:200, Molecular Probes).

\section{Quantitative analyses of dendritic spines and synapses.}

Dendritic spines: Two approaches were applied to evaluate the number and density of dendritic spines in Golgi-stained sections. 1) Spines in area CA1 were counted with the aid of Stereo Investigator (MBF Bioscience, Williston, VT, USA) using stereological fractionator method $[39,40]$. Section series (every third section) from dorsal hippocampus was subjected to counting. Strata radiatum (SR) and lacunosummoleculare (SLM) in area CA1 were defined using a $5 \times$ objective and spines were counted using a $100 \times / 1.4$ objective. We used a counting frame of $25 \times 25 \mu \mathrm{m}$, a sampling grid of $200 \times 200 \mu \mathrm{m}$, a guard zone of 10 $\mu \mathrm{m}$ and disector height of $50 \mu \mathrm{m}$. 2) Spine density (number of spines per $20 \mu \mathrm{m}$ of dendrite length) was calculated on individual CA1 pyramidal cells (3-4 cells per brain, 28-36 cells per group). Well impregnated cells were captured with a Nikon E400 equipped with a CCD camera (DS-Fi3) and motorized stage and reconstructed using Imaris (v7.1.0) and Adobe Photoshop (v6). Cells in each group included equal representation of long- and short-shaft populations [33]. High-magnification images $(100 \times / 1.4$ oil lens) permitted all spines of a given dendritic segment to be visualized. The sides of dendritic branch were carefully examined for vertical protrusions stretching upward and downward off the branch. Branches including basal dendrites in the oriens (SO), apical obliques in SR, and apical distal branches in SLM were analyzed. The apical trunk was not analyzed because some spines that extended vertically toward the observer were difficult to classify from an aerial perspective. Density of spines on each branch was separately analyzed with the aid of concentric circles at an interval of $20 \mu \mathrm{m}$. The data were grouped by cell and then by animal. Spines were classified by size and shape as mushroom-type, thin, and stubby [33, 41].

Synapses: The number of synapses represented by PSD-95 immunoreactive (ir) puncta were quantitatively analyzed as described [32, 33]. Briefly, 10 sections (90 $\mu \mathrm{m}$ interval each other) per animal were used and $z$-stack images were taken from the regions of interest using a Zeiss 510 confocal microscope with a $63 x$ objective. The region of interest was defined using a $4 \times$ objective and images were then captured using a $63 \times / 0.8$ objective. We used a counting frame of $25 \times 25 \mu \mathrm{m}$, a sampling grid of $200 \times 200 \mu \mathrm{m}$, a guard zone of $10 \mu \mathrm{m}$ and a disector height of $5 \mu \mathrm{m}$. The precision of the study was estimated by calculating the coefficient of error (CE). The CE value for each individual animal ranged between 0.02 and 0.05 . Confocal 
three-dimensional image stacks were processed for iterative deconvolution at $99 \%$ confidence (Volocity 6.3). Counts (per $7,500 \mu \mathrm{m}^{3}$ ) of labeled puncta from each section were averaged to obtain a value for each brain. Sections from four groups were processes concurrently and analyzed without knowledge of treatment group.

\section{Preparation of protein extracts and Western blot analyses of synaptic proteins.}

Dorsal hippocampus was quickly dissected and area CA1 was further isolated. Dissected tissue was immediately frozen in dry ice and then homogenized in T-PER Tissue Protein Extraction Reagent (ThermoFisher Scientific, Rockford, IL) (150 mg/ml) containing protease and phosphatase inhibitor cocktail (1:100, Sigma-Aldrich, St. Louis, MO). The sample was centrifuged at $100,000 \times \mathrm{g}$ for 1 hour. The pellet was re-suspended with $70 \%$ formic acid, followed by centrifugation at $100,000 \times \mathrm{g}$ for another hour. Protein concentration in the supernatant was determined using the Bradford assay.

Equal amounts of protein $(20 \mu \mathrm{g})$ were diluted in Laemmli buffer, separated on $4-12 \%$ Bis-Tris gel (Invitrogen, Carlsbad, CA), and transferred to nitrocellulose membranes. The membranes were blocked with $5 \%$ nonfat milk in $1 \times$ TBS-T overnight at $4{ }^{\circ} \mathrm{C}$, followed by incubation in primary antibodies overnight at $4^{\circ} \mathrm{C}$. The antibodies included mouse anti-PSD95 (1:5,000, clone 7E3-1B8), rabbit anti-GluR1 (1:2,000; PC246, Calbiochem), and mouse anti-synaptophysin (1:10,000, Sigma). The membranes were washed in TBS-T ( $3 \times 5 \mathrm{~min})$ and incubated in appropriate secondary antibody (anti-rabbit lgG or anti-mouse $\lg$ conjugated to HRP) at a dilution of 1:10,000 (Pierce Biotech) for $1 \mathrm{hr}$ at RT. Membranes were then washed in TBS-T $(3 \times 5 \mathrm{~min})$ and the blots were developed using SuperSignal (Thermo Scientific). Hippocampal extracts of individual mice of different groups were run concurrently on the same gel. Specificity of signal was verified by pre-adsorbing primary antibodies with their respective antigens as well as by excluding the primary antibodies in the presence of the secondary antibodies. These treatments resulted in no immunoreactive bands.

\section{Analyses of A $\beta$ peptides, oligomers, and APP secretases.}

ELISA of $A \beta$ peptides: $A \beta_{1-38}, A \beta_{1-40}$, and $A \beta_{1-42}$ were measured using the $6 E 10$ Abeta Peptide UltraSensitive Kits (K151FSE, K151FTE, and K151FUE, respectively, MSD, Rockville, MD, USA) [40]. T-PER soluble fractions from dorsal hippocampus were loaded directly onto the ELISA plate, and the formic acid supernatants (insoluble fractions) were diluted 1:2 in neutralization buffer ( $1 \mathrm{M}$ Tris base and $0.5 \mathrm{M} \mathrm{NaH}_{2} \mathrm{PO}_{4}$ ) 
before loading. After incubation in blocking solution, samples and standard peptides including $A \beta_{1-38}, A \beta_{1}$ 40 , and $A \beta_{1-42}$ were added to the 96 -well plate and incubated overnight $\left(4^{\circ} \mathrm{C}\right)$, followed by washes in $1 \times$ Tris wash buffer $(3 \times 5 \mathrm{~min})$. After $1 \mathrm{hr}$ incubation in detection solution $(\mathrm{RT})$, the plate was washed with $1 \times$ Tris buffer, and read in a Sector Imager plate reader (MSD) immediately after addition of the $1 \times$ read buffer. The concentrations of $A \beta$ peptides were calculated with reference to the standard curves and expressed as picograms per milligrams of proteins.

Dot-blot of $A \beta$ oligomers and amyloid fibril: Equal amounts of protein $(3 \mu \mathrm{g})$ were transferred to nitrocellulose membranes, and the membranes were blocked with $5 \%(\mathrm{w} / \mathrm{v})$ nonfat milk in $1 \times$ Tris-buffered saline containing $0.2 \%$ Tween 20 (TBS-T, pH 7.5) for $1 \mathrm{hr}$ at RT. The membranes were then incubated overnight at $4^{\circ} \mathrm{C}$ with one of the following primary antibodies: rabbit anti-oligomer (A11) polyclonal (AHB0052, 1:1,000, ThermoFisher) and rabbit anti-amyloid fibrils OC (AB2286, 1:3,000, Sigma-Aldrich). A11 reacts with soluble AB40 oligomers, but not with soluble low molecular weight $A B 40$ or $A B 40$ fibrils. The membranes were washed in TBS-T $(3 \times 5 \mathrm{~min})$ and incubated in goat anti-rabbit $\lg \mathrm{G}$ secondary antibody $(1: 10,000$; ThermoFisher) for $1 \mathrm{hr}$ at RT. The blots were developed using SuperSignal chemiluminescent substrates (ThermoFisher).

Western blot analyses of APP and secretases: Equal amounts of protein $(20 \mu \mathrm{g})$ were diluted and transferred to nitrocellulose membranes as described above. The membranes were blocked with $5 \%$ nonfat milk in $1 \times$ TBS-T overnight at $4^{\circ} \mathrm{C}$, followed by incubation in primary antibodies overnight at $4^{\circ} \mathrm{C}$. The antibodies included rabbit anti-APP-CT20 for C99 and C83 (1:1,000, Calbiochem, San Diego, CA), rabbit anti-ADAM10 (1:1,000, MA5-32616, ThermoFisher), rabbit anti-ADAM17 (1:1,000, PA5-11572, ThermoFisher), rabbit anti-BACE1 (1:1,000, MA5-35126, ThermoFisher), and mouse anti-GAPDH (1:5,000, sc-47724, Santa Cruz Biotech, Santa Cruz, CA). The membranes were incubated in appropriate secondary antibody, and the blots were developed using SuperSignal as described.

\section{Statistical analysis.}

Data were analyzed using Prism 9 (GraphPad Software Inc.) or SPSS 22.0 (SPSS Inc.). Analyses of variance (ANOVA) including two-way and three-way were used to detect differences in the escape latencies, path lengths, and swimming speeds in water maze task with groups (Ntg vs. 3xTg-AD, sedentary vs. running) and time (day) as factors, followed by Tukey's or Bonferroni's post hoc test. Two-way ANOVA was 
employed to compare the exploration times and novel/familiar ratios among groups. Spines, synapses, and synaptic proteins were analyzed by three-way or two-way ANOVA with groups and branch segment and/or subregion/subtype as factors, followed by Tukey's or Bonferroni's post hoc test. One-sample $t$-test was also performed to distinguish whether exploration times of objects were different from those predicted by chance. Pearson test was used for the correlation analysis. Data were expressed as mean \pm SEM, significance was set at $95 \%$ confidence.

\section{Results}

\section{Voluntary physical running improves spatial memory function.}

The effects of voluntary running on spatial memory were investigated in two cohorts of 3xTg-AD mice via an object location task and a water maze task, respectively. In the object location task (Fig. $1 \mathbf{A}-\boldsymbol{C}), 3 x \operatorname{Tg}$ AD sedentary controls ( 7 months old) explored the two objects equally (one-sample $t$-test, $t_{11}=0.81, P=$ 0.43), and had declined memory as compared with age-matched Ntg sedentary mice (two-way ANOVA, $F_{[1,43]}=57.30, P<0.0001$; post hoc test, $P<0.01$ ), which was consistent with published data (Billings et al., 2005; Baglietto-Vargas et al., 2015). However, running wheel for 5 months improved memory in either 3xTg-AD or Ntg mice (two-way ANOVA, $F_{[1,43]}=38.51, P<0.0001$ ). The novel/familiar ratio of $3 x \operatorname{Tg}-\mathrm{AD}$ runners was significantly higher than that of 3xTg-AD sedentary mice (Tukey's post hoc test, $P<0.01$ ). Ntg runners also had an increased ratio of novel/familiar versus Ntg sedentary controls $(P<0.05)$, supporting the beneficial effects of running on spatial memory. No differences were detected in total exploration time in both training and testing phases $(P>0.05)$.

In the water maze task (Fig. 1D-H), 3xTg-AD runners had improved spatial memory to search the original location of the platform. Whereas 3xTg-AD sedentary controls spent almost equal time in four quadrants (one-way ANOVA, $F_{[3,44]}=1.61, P=0.20$; post hoc test, $P>0.05$ ), $3 \times \mathrm{Tg}-\mathrm{AD}$ runners frequently explored in the NW platform quadrant $\left(F_{[3,40]}=42.63, P<0.0001\right.$; post hoc test, $\left.P<0.05\right)$ and had a higher \% time in platform quadrant than $3 \times \mathrm{Tg}-\mathrm{AD}$ sedentary controls (two-way ANOVA, $F_{[1,41]}=10.72, P=0.002$; post hoc test, $\left.{ }^{*} P<0.05\right)$. Similar to the Ntg mice, the $3 \times \mathrm{Tg}-\mathrm{AD}$ runners had higher numbers in crossing the location of the removed platform than 3xTg-AD sedentary controls (two-way ANOVA, $F_{[1,41]}=14.64, P=0.0004$; post hoc test, ${ }^{*} P<0.05$ ). During the 5 -day training, mice required progressively less time (three-way ANOVA, $F_{[4,205]}=131.20, P<0.0001$ ) and swam shorter distance (three-way ANOVA, $F_{[4,205]}=216.10, P<$ 0.0001 ) to find a hidden platform. Differences were not observed on swimming speeds among the groups 
(two-way ANOVA, $F_{[3,217]}=0.94, P=0.42$ ), although the speeds decreased slightly across the training (three-way ANOVA, $F_{[4,205]}=21.69, P<0.0001$ ). On day 5 and 4 of the training, $3 x T g-A D$ runners spent less time and swam short path to reach the hidden-platform compared with 3xTg-AD sedentary mice (post hoc test, ${ }^{*} P<0.01$ ), suggesting improved learning and memory ability in $3 \times \mathrm{Tg}-\mathrm{AD}$ runners.

\section{An enormous effect of physical running on dendritic spines in 3xTg-AD mice.}

Our previous studies on aged mice have revealed that running wheel for 5 months can protect against aging-related loss of dendritic spines on CA1 hippocampal cells, which is important for restoring spatial memory function in aging mice [31, 32, 33]. We thus focused on area CA1 and explored the effect of running on spines in 3xTg-AD mice when they completed a spatial memory performance. Dendritic spines were evaluated via two approaches: unbiased stereological counting and reconstructed pyramidal cell analysis.

The spines were first counted in strata oriens (SO), radiatum (SR), and lacunosum-moleculare (SLM) of area CA1 via unbiased stereological fractionator method (Fig. 2). Two-way ANOVA analyses revealed a running-induced alteration in number of spines in SO, SR, and $\operatorname{SLM}\left(F_{[1,43]}=52.05, F_{[1,43]}=38.84, F_{[1,43]}=\right.$ 26.36, respectively, all $P<0.0001)$. Increased spine number was apparent in 3xTg-AD runners compared with 3xTg-AD sedentary controls (Tukey's post hoc test, ${ }^{* *} P<0.01$ ) as well as in Ntg runners versus Ntg controls $\left({ }^{*} P<0.05\right)$. A genotype-related difference in spine numbers was also detected in $\mathrm{SO}, \mathrm{SR}$, and $\operatorname{SLM}\left(F_{[1,43]}=244.0, F_{[1,43]}=97.34, F_{[1,43]}=62.85\right.$, respectively, all $\left.P<0.0001\right)$ with lower spine numbers in 3xTg-AD sedentary mice versus Ntg controls (Tukey's post hoc test, ${ }^{* *} P<0.01$ ). As spines in adult hippocampus are classified into three subtypes (thin, mushroom-type, and stubby) that differently involved in learning and memory processes $[31,42,43]$, we asked whether increased number of spines in the runners originated from specific type of spines. Interestingly, 3xTg-AD runners had more thin spines in SO and SR (three-way ANOVA, $F_{[1,129]}=53.17$ and $F_{[1,129]}=43.16$, respectively, all $P<0.0001$; post hoc test, $\left.{ }^{* *} P<0.01\right)$ and more mushroom-type spines in SO, SR, and SLM $\left({ }^{* *} P<0.01\right)$ compared with 3xTg-AD sedentary controls. In Ntg runners, thin spines were higher in SO and $\mathrm{SR}\left({ }^{* *} P<0.01\right)$ but mushroom-type spines were not affected $(P>0.05)$ compared with Ntg sedentary controls.

The spines were further analyzed on the basal and apical dendrites of reconstructed individual CA1 pyramidal cells, considering that the distribution of spines is highly branch-dependent (Fig. 3). As expected, a lower density of spines on basal and apical dendrites was apparent in 3xTg-AD sedentary mice versus 
Ntg sedentary mice (three-way ANOVA, $F_{[1,129]}=144.8, P<0.0001$; post hoc test, ${ }^{* \star} P<0.01$ ). Running protected against the loss of spines on CA1 pyramidal cells $\left(F_{[1,129]}=88.64, P<0.0001\right)$. Spines on either basal or apical dendrites were well reserved in $3 \times T g-A D$ runners compared with $3 x T g-A D$ sedentary controls $\left({ }^{* *} P<0.01\right)$. Notably, running affected both thin and mushroom-type spines on the basal dendrites $\left(F_{[1,129]}=10.17, P=0.0018\right)$ as well as on apical dendrites (in SR: $F_{[1,129]}=58.53, P<0.0001$; in SLM: $F_{[1,129]}$ $=13.37, P=0.0004$. Tukey's post hoc test, $\left.{ }^{* \star} P<0.01\right)$ in $3 \times \operatorname{Tg}-\mathrm{AD}$ mice. However, the effect of running in Ntg mice was limited to thin spines on apical dendrites in $\operatorname{SR}\left(F_{[2,129]}=252.5, P<0.0001\right.$; post hoc test, ${ }^{* \star} P$ $<0.01$ ) (Fig. 3E). Together, physical running protected against the loss of spines on CA1 pyramidal cells in 3xTg-AD mice, and this effect was extensively occurred on thin and mushroom-type spines.

\section{Physical running alleviates synaptic deficits in 3xTg-AD mice.}

To explore the synaptic basis of the beneficial effects of running on spatial memory and dendritic spines, we measured the expression of synaptic proteins and counted the synapses in dorsal hippocampus. The protein levels of postsynaptic density protein-95 (PSD-95), AMPA glutamate receptor subunit GluR1, and synaptophysin (the major synaptic vesicle protein p38 located in presynaptic terminal buttons) were measured in CA1 of 3xTg-AD and Ntg mice with or without running via Western blot assays (Fig. 4). 3xTgAD running mice had elevated levels of synaptic proteins compared with 3xTg-AD sedentary controls (twoway ANOVA, $F_{[1,20]}=46.85,13.38$, and 28.13 for PSD-95, GluR1, and synaptophysin, respectively; Tukey's post hoc test, $\left.{ }^{* *} P<0.01\right)$. Ntg runners had higher expressions of PSD-95 $\left({ }^{* *} P<0.01\right)$ and synaptophysin $\left({ }^{\star} P<0.05\right)$ versus Ntg sedentary controls. As expected, decreased expression of synaptic proteins was apparent in 3xTg-AD sedentary mice compared with $\operatorname{Ntg}$ sedentary mice $\left(F_{[1,20]}=76.31,51.07\right.$, and 64.84 for PSD-95, GluR1, and synaptophysin, respectively; all $P<0.0001$. The post hoc test, ${ }^{* \star} P<0.01$ ).

The expression of PSD-95 was further evaluated on immunostaining sections in view of that PSD-95 has been detected on both thin and mushroom-type spines and PSD-95-immunoreactive (ir) puncta can represent synapses in the hippocampus [33]. PSD-95-ir puncta were stereologically counted in SO, SR, and SLM, the subregions of area CA1. As shown in Fig. 4, loss of PSD-95-ir puncta/synapses was apparent in all measured regions in 3xTg-AD sedentary mice compared with Ntg sedentary controls (three-way ANOVA, genotype $\times$ running $\times$ region, $F_{[1,60]}=121.2, P<0.0001$; post hoc test, $\left.{ }^{* \star} P<0.01\right)$. The $3 \times \mathrm{Tg}-\mathrm{AD}$ runners had comparable numbers of synapses in measured regions versus Ntg mice, which are higher than that in 3xTg-AD sedentary controls (three-way ANOVA, $F_{[1,60]}=77.64, P<0.0001$; post hoc test, ${ }^{* *} P<$ 
0.01). Notably, the effects of running on PSD-95-ir puncta were limited to SR in Ntg mice. Taken together, these data are consistent with the effects of running on dendritic spines in area CA1, supporting the conclusion that prolonged voluntary running protects against loss of spines and synapses in hippocampal CA1 of $3 x \operatorname{Tg}-A D$ mice.

\section{Physical running reduces the levels of $A \beta$ peptides and oligomers in 3xTg-AD mice.}

Given the enormous effects of running on spines/synapses and synaptic proteins in 3xTg-AD mice than in Ntg mice, we investigated whether prolonged running had any effects on A $\beta$ peptides and oligomers (Fig. 5). At the end of a water maze testing, a group of $3 \times \mathrm{Tg}-\mathrm{AD}$ running mice was compared with $3 \times \mathrm{Tg}-\mathrm{AD}$ sedentary mice $(n=8)$. Lower levels of soluble $A \beta$ including $A \beta_{1-38}$ and $A \beta_{1-40}$ were detected in $3 x \operatorname{Tg}-A D$ runners compared with sedentary controls (two-way ANOVA, running $\times$ peptide subtype, $F_{[1,42]}=55.62, P$ $<0.0001$; post hoc test, ${ }^{*} P<0.05$ for $A \beta_{1-40}$ and ${ }^{* \star} P<0.01$ for $\left.A \beta_{1-38}\right)$. A lower ratio of $A \beta_{1-42} / A \beta_{1-40}$ was found in the runner versus controls $\left({ }^{*} P<0.05\right)$ (Fig. $5 A$ ). Lesser insoluble $A \beta_{1-38}$ and $A \beta_{1-40}$ were also measured in $3 x \operatorname{Tg}-\mathrm{AD}$ runners $\left(F_{[1,42]}=22.50, P<0.0001\right.$; post hoc test, ${ }^{*} P<0.05$ for $\mathrm{A} \beta 1-40,{ }^{* \star} P<0.01$ for $A \beta 1-38$ ) (Fig. 5B). Notably, the levels of $A \beta$ peptides correlated with spatial memory performance. Specifically, the \% time in platform quadrant negatively correlated with the measured levels of soluble and insoluble $A \beta$ peptides in hippocampal CA1 (Fig. 5C,D).

Dot-blot data suggested reduced levels of $A \beta$ oligomers positive for $A B 40$ oligomers ( $A 11)$ and amyloid fibril (OC) in 3xTg-AD runners $\left(F_{[1,28]}=48.51, P<0.0001\right.$; post hoc test, $\left.{ }^{* *} P<0.01\right)$ (Fig. 5E). To explore whether APP processing was involved in running-provoked decrease of A $\beta$ peptides and oligomers, full-length APP and APP C-terminal fragments C99 and C83 were measured via Western-blot analyses. No difference was observed on steady-state levels of full-length APP holoprotein between 3xTg-AD runners and sedentary controls (two-way ANOVA, $F_{[1,42]}=173.4, P<0.0001$; post hoc test, $P=0.08$ ). However, C99 and C83 were downregulated in the runners $\left(F_{[1,42]}=173.4, P<0.0001\right.$; post hoc test, $\left.{ }^{* *} P<0.01\right)$ (Fig. 5F). Considering that the cleavage of APP requires $\alpha$-secretase and $\beta$-secretase, $\alpha$-secretases ADAM 10 and ADAM 17 as well as $\beta$-site APP cleaving enzyme 1 (BACE1) were further analyzed (Fig. 5G). Decreased ADAM 17 and BACE1 were apparent in 3xTg-AD runners compared with sedentary controls $\left(F_{[1,56]}=103.0\right.$, $P<0.0001$; post hoc test, $\left.{ }^{* *} P<0.01\right)$. Together, these data suggest that running-provoked decrease of $A \beta$ levels may be caused by the downregulation of APP processing. 


\section{Discussion}

Physical exercise has a wide spectrum of impact on brain structure, which is beneficial to memory health. Here we observe the effects of prolonged wheel running on defective spatial memory in a triple-transgenic mouse model of $A D(3 \times T g-A D$ mouse) and investigate its underlying mechanisms. The major findings are as follows. (i) Voluntary running improves hippocampal-dependent spatial memory in 3xTg-AD mice. (ii) Daily running ( 1 hour per day) for 5 months prevents loss of dendritic spines on CA1 pyramidal cells in 3xTg-AD mice. The beneficial effects of running on spines are accompanied by increased individual synapses and enhanced expression of synaptic proteins including PSD-95, GluR1, and synaptophysin in area CA1. (iii) The effects of running on spines are enormous in 3xTg-AD mice compared with Ntg mice, represented by both thin and mushroom-type spines preserved in 3xTg-AD mice, while only thin spines are selectively prevented in Ntg mice. (iv) Running at a moderate pace reduces the levels of $A \beta$ peptides and oligomers via downregulating APP processing. Particularly, running-induced enhancement of memory performance correlates with a reduced level of $A \beta$ peptides in the dorsal hippocampus.

Physical exercise can improve cognitive function and reduce the risk of $A D$ [e.g., 44-46]. Patients with $A D$ dementia have better outcomes including improved memory and cognitive behavior when they start exercising regularly $[8,9,10,11,12,13,14,15,18,47]$. The current studies provide evidence for the beneficial effect of voluntary running on spatial memory and its underlying mechanisms in 3xTg-AD mice. Because the 3xTg-AD mice display cognitive impairments by 6 months of age $[48,49]$ in a sex-dependent manner [50, 51, 52], male mice are employed in the study and all memory performances are tested at 7 months old. During the training days of a water maze memory task, 3xTg-AD mice spend more time and swim in a longer path to find the platform on the last two days of training compared with Ntg mice, suggesting that these 3xTg-AD mice have impaired learning and memory, which is consistent with previous reports [40, 48]. Running for 5 months improves spatial memory in 3xTg-AD mice as well as in nontransgenic wild-type mice, supported by the fact that when these mice are tested in a probe trial in which the hidden-platform is removed, the runners crossed the location of the removed platform more frequently than sedentary controls. 3xTg-AD runners also spent a larger percentage of time in the platform quadrant. Furthermore, data from the object location task imply that memory decline is apparent in 3xTg-AD sedentary mice compared with Ntg controls, confirming the declined memory observed in the water maze. Similarly, $3 x T g-A D$ running mice have improved memory, indicated by a higher ratio of novel to familiar location 
exploration compared to Ntg sedentary controls, further supporting the beneficial effects of physical running on spatial memory.

How could physical running help prevent loss of spatial memory in 3xTg-AD mice? Spatial memory largely relies on the integrity of structural components of synaptic connections in area CA1 of the dorsal hippocampus. In CA1, pyramidal cells harbor numerous spines, representing the main target of excitatory synaptic inputs including the Schaffer axon terminals and entorhinal fibers [53, 54]. These pathways are highly associated with hippocampal-dependent spatial navigation $[55,56]$. Generally, defeat of postsynaptic targets may result in degeneration of presynaptic elements, leading to loss of synaptic connections. Therefore, the conservation of dendritic spines in area CA1 will benefit synaptic connections and spatial memory. Our studies on normal aging mice have shown that physical running initiated at an older age and lasted for 5 months enhances hippocampal-dependent memory function in the mice. Particularly, enhanced memory performance correlates with increased density of dendritic spines in area CA1 in old running mice $[31,32]$. Here, the number and types of spines are analyzed on CA1 pyramidal cells. Focusing on thin and mushroom-type spines, a significant loss of both thin and mushroom-type spines is found in $3 \times \operatorname{Tg}-A D$ sedentary mice compared with age-matched non-transgenic mice. However, 3xTg-AD mice subjected to 5 months of running have a higher density of spines compared with age-matched sedentary controls. Interestingly, 3xTg-AD running mice have increased numbers of both thin and mushroom-type spines on CA1 pyramidal cells, distinctive from the selective effect of running on thin spines in Ntg mice. The limited effect of running observed in Ntg mice is consistent with our reports on aged C57 mice, which found that 5 months of running protects against age-related loss of thin spines and small synapses in the hippocampus $[31,33]$. An increased number of spines in area CA1 provides more chances for forming synaptic contacts in this area, a basis of enhanced synaptic plasticity and memory function. Further studies are needed to understand the mechanisms responsible for the profound effect of running on both thin and mushroom-type spines in the hippocampus of $3 \times \mathrm{Tg}-\mathrm{AD}$ mice.

The beneficial effects of physical running on dendritic spines in 3xTg-AD mice are accompanied by a measurable change of synapses and enhanced expression of synaptic proteins. The analysis of PSD-95-ir puncta in area CA1 suggests increased synapses in 3xTg-AD running mice, supporting the effects of running on dendritic spines, because PSD-95 is detected on either mushroom-type spines or thin spines $[33,57]$. Increased PSD-95-ir puncta in all examined subfields of 3xTg-AD running mice further reveals the 
profound effects of long-term voluntary running in 3xTg-AD mice. The protein levels of PSD-95 and GluR1 measured by Western blot are consistent with the analyses of thin and mushroom-type spines. Increase expression of GluR1 has been detected in 3xTg-AD running mice versus 3xTg-AD sedentary controls, suggesting the preservation of mushroom-type spines and big synapses, because AMPA receptors are rarely detected on thin spines and small synapses [58, 59], and GluR1-ir puncta have been used as a synaptic marker to represent mushroom-type spines [33]. In the current studies, we have further examined the expression of synaptophysin, a major synaptic vesicle protein located in the presynaptic terminals [32]. Synaptophysin is found in all types of synapses and is important for synaptic integrity [60, 61]. Synaptophysin immunoreactivity completely matches with the synaptic profile distribution, and increased expression of synaptophysin is accompanied by the formation of synapses [60]. Previous studies from patients with $A D$ have suggested that synaptophysin is more vulnerable than other synaptic proteins, such as syntaxin or SNAP-25, and loss of synaptophysin is an early event that correlates with initial cognitive impairment $[62,63,64]$. Consistent with the loss of postsynaptic targets, reduced expression of synaptophysin is apparent in area CA1 of $3 x \operatorname{Tg}-A D$ sedentary mice. Interestingly, daily voluntary running for 5 months prevents the loss of synaptophysin in the 3xTg-AD mice, which may contribute to the protective effect of running on memory function as indicated by the correlation analyses in our previous aging study [32]. Taken together, these data suggest that prolonged voluntary running prevents the loss of pre- and postsynaptic proteins in 3xTg-AD mice.

It is interesting to note that dendritic spines and synaptic proteins are largely protected in 3xTg-AD runners compared to non-transgenic runners. Given that $A \beta$ is critical to the early stage of synaptic failure seen in $A D$ pathogenesis [65] and that intracellular $A \beta$ pathogenesis precedes the appearance of tau pathology in the $3 \times \operatorname{Tg}-A D$ mice $[48,66]$, we investigated the potential effects of physical running on $A \beta$ pathology in area CA1. Accumulation of $A \beta$ in the brain is an early and specific phenomenon associated with the progression of AD. Specifically, A oligomers can bind to synaptic sites [67] and lead to a loss of spines in organotypic hippocampal slice cultures $[37,68]$. The current studies find that wheel running for 5 months decreases the levels of both soluble and insoluble $A \beta$ peptides as well as the formation of $A \beta$-oligomers. Among these peptides, soluble $A \beta_{1-38}$ and $A \beta_{1-40}$ are significantly decreased in the $3 x T g-A D$ runners compared with sedentary controls. The insoluble $A \beta_{1-38}$ and $A \beta_{1-40}$ are also downregulated in the $3 \times \mathrm{Tg}-A D$ runners. Particularly, a decreased ratio of soluble $A \beta_{1-42}$ versus soluble $A \beta_{1-40}$ is detected in $3 \times T g-A D$ runners compared with their sedentary controls, supporting the note that the $A \beta_{1-42} / A \beta_{1-40}$ ratio could serve as a 
marker of imminent onset or progression of $A D[69,70]$. Evidence has revealed that $A \beta_{1-42}$ is the most fibrillogenic and the predominant component of amyloid plaques in AD [71]. Although we find that running has limited influence on $A \beta_{1-42}$ in area $C A 1$, a tendency of decreased $A \beta_{1-42}$ is observed in the runners, and the levels of $A \beta_{1-42}$ including soluble and insoluble fragments negatively correlate with spatial memory performance. Furthermore, prolonged running has apparent beneficial effects on $A \beta$ oligomers, reducing the oligomers positive for $A B 40$ and amyloid fibril in 3xTg-AD runners. It is known that $A \beta$ is generated from $\beta$-amyloid precursor protein (APP) through sequential proteolytic cleavages by a group of secretases. The overexpression of APP in either dendritic or axonal compartments may lead to reduced spine density and plasticity in nearby neurons [72]. Here we find that running downregulates APP C-terminal fragments C99 and C83 as well as $\alpha$-secretases ADAM 17 and $\beta$-secretase BACE1 in 3xTg-AD mice, suggesting that running-provoked downregulation of $A \beta$ pathogenesis occurs in part by modulating APP processing. The correlation analyses further suggest the importance of $A \beta$ peptides in spatial memory performance, as the levels of $A \beta$ in area CA1 negatively correlate with memory performance. Taken together, it is plausible that prolonged voluntary running may significantly protect the dendritic spines and synapses by decreasing $A \beta$ levels, contributing to improved memory function.

\section{Limitations}

Additional works should be carried out to identify the causal link between spine collapse and amyloid beta accumulation. Studies are also needed to know the molecules that are responsible for the profound effects of prolonged running on both thin and mushroom-type spines in the hippocampus.

\section{Conclusions}

Prolonged voluntary running improves hippocampal dependent spatial memory and reduces the accumulation of $A \beta$ peptides and oligomers in 3xTg-AD mice. The enormous effects of running on dendritic spines and synaptic proteins in hippocampal area CA1 in the AD model mice compared with non-transgenic mice indicate that voluntary running may protect dendritic spines and synapses by reducing amyloid beta levels. These data suggest that prolonged running improves spatial memory in preclinical AD via slowing down amyloid pathology and preventing loss of synaptic contacts. 


\title{
List of abbreviations:
}

\author{
$A \beta$ : amyloid-beta \\ AD: Alzheimer's disease \\ APP: amyloid precursor protein \\ BACE1: beta-site amyloid precursor protein cleaving enzyme 1 \\ GluR1: glutamate receptor subunit 1 \\ PSEN1: presenilin-1 \\ PSEN2: presenilin-2 \\ PSD-95: postsynaptic density protein-95 \\ Ntg: non-transgenic controls
}




\section{Declarations}

Ethics approval and consent to participate: All procedures were performed in accordance with the National Institutes of Health Guide for Care and Use of Laboratory Animals and approved by the Bioethics Committees of the Yangtze University and Guangzhou Medical University.

This article does not contain any studies with human participants performed by any of the authors.

Consent for publication: All authors read and approved the final manuscript.

Availability of data and materials: All data needed to evaluate the conclusions in the paper are present in the paper. Additional data related to this paper may be requested from the authors.

Competing interest: The authors declare no competing interest.

Funding: The study was supported by the Yangtze University Medical Science Foundation (WJ2019-19), the Yangtze Fund for Youth Teams of Science and Technology Innovation (No.2016cqt04), the Health Commission of Hubei Province of China (WJ2018H189, WJ2021Q015), the High-Level Construction Fund of Guangzhou Medical University (Grant no. 195002002033), and the National Natural Science Foundation of China (81871004).

Authors' contributions: D. Long, Y. Chen, and B. Xu designed research; Y. He, B. Xu, L. Liu, G. Ye, L. Cheng, and Q. Wang performed research; M. Chen counted spines; B. Xu, Y. He, and L. Liu analyzed data; and B. Xu, D. Long, and Y Chen wrote and edited the paper. All authors read and approved the final version of the manuscript.

Acknowledgements: Not applicable. 
Funding receivers (all the supports were made to receivers, not the institutions):

Yun He: Yangtze University Medical Science Foundation (WJ2019-19);

Yun He: Health Commission of Hubei Province of China (WJ2018H189);

Lian Liu: Yangtze Fund for Youth Teams of Science and Technology Innovation (No.2016cqt04);

Lian Liu: Health Commission of Hubei Province of China (WJ2021Q015);

Dahong Long: High-Level Construction Fund of Guangzhou Med Univ. (Grant no. 195002002033);

Dahong Long: National Natural Science Foundation of China (81871004).

\section{List of email addresses:}

Benke Xu: xubenke@139.com

Yun He: $\underline{\text { mrheyun@foxmail.com }}$

Lian Liu: liulian@yangtzeu.edu.cn

Guosheng Ye: 552097271@qq.com

Lulu Chen: chenlulu7230@163.com

Qingning Wang: 773522602@qq.com

Michael Chen: whtbalverine3@gmail.com

Dahong Long: longdahong88@qq.com

Yuncai Chen: yuncaic@uci.edu 


\section{References:}

1. Long JM, Holtzman DM. Alzheimer disease: an update on pathobiology and treatment strategies. Cell. 2019; 179(2):312-339.

2. Fan L, Mao C, Hu X, Zhang S, Yang Z, Hu Z, Sun H, Fan Y, Dong Y, Yang J, Shi C, Xu Y. New insights into the pathogenesis of Alzheimer's disease. Front Neurol. 2020; 10:1312.

3. Fenoglio C, Scarpini E, Serpente M, Galimberti D. Role of genetics and epigenetics in the pathogenesis of Alzheimer's disease and frontotemporal dementia. J Alzheimers Dis. 2018; 62(3):913-932.

4. Crous-Bou M, Minguillón C, Gramunt N, Molinuevo JL. Alzheimer's disease prevention: from risk factors to early intervention. Alzheimers Res Ther. 2017; 9(1):71.

5. Maiti P, Bowers Z, Bourcier-Schultz A, Morse J, Dunbar GL. Preservation of dendritic spine morphology and postsynaptic signaling markers after treatment with solid lipid curcumin particles in the 5xFAD mouse model of Alzheimer's amyloidosis. Alzheimers Res Ther. 2021; 13(1):37.

6. Busche MA, Hyman BT. Synergy between amyloid-beta and tau in Alzheimer's disease. Nat Neurosci. 2020; 23(10):1183-1193.

7. Hötting K, Röder B. Beneficial effects of physical exercise on neuroplasticity and cognition. Neurosci Biobehav Rev. 2013; 37(9 Pt B):2243-2257.

8. Okonkwo OC, Schultz SA, Oh JM, Larson J, Edwards D, Cook D, Koscik R, Gallagher CL, Dowling NM, Carlsson CM, Bendlin BB, LaRue A, Rowley HA, Christian BT, Asthana S, Hermann BP, Johnson SC, Sager MA. Physical activity attenuates age-related biomarker alterations in preclinical AD. Neurology. 2014; 83(19):1753-1760.

9. Brini S, Sohrabi HR, Peiffer JJ, Karrasch M, Hämäläinen H, Martins RN, Fairchild TJ. Physical activity in preventing Alzheimer's disease and cognitive decline: a narrative review. Sports Med. 2018; 48(1):29-44.

10. Müller S, Preische O, Sohrabi HR, Gräber S, Jucker M, Ringman JM, Martins RN, McDade E, Schofield PR, Ghetti B, Rossor M, Fox NN, Graff-Radford NR, Levin J, Danek A, Vöglein J, Salloway S, Xiong C, Benzinger T, Buckles V, Masters CL, Sperling R, Bateman RJ, Morris JC, Laske C; Dominantly Inherited Alzheimer Network (DIAN). Relationship between physical activity, cognition, and Alzheimer pathology in autosomal dominant Alzheimer's disease. Alzheimers Dement. 2018; 14(11):1427-1437.

11. Northey JM, Cherbuin N, Pumpa KL, Smee DJ, Rattray B. Exercise interventions for cognitive function in adults older than 50: a systematic review with meta-analysis. Br J Sports Med. 2018; 52(3):154-160.

12. Panza GA, Taylor BA, MacDonald HV, Johnson BT, Zaleski AL, Livingston J, Thompson PD, Pescatello LS. Can exercise improve cognitive symptoms of Alzheimer's disease? J Am Geriatr Soc. 2018; 66(3):487-495.

13. Brown BM, Peiffer J, Rainey-Smith SR. Exploring the relationship between physical activity, betaamyloid and tau: a narrative review. Ageing Res Rev. 2019; 50:9-18.

14. Jia RX, Liang JH, Xu Y, Wang $Y Q$. Effects of physical activity and exercise on the cognitive function of patients with Alzheimer disease: a meta-analysis. BMC Geriatr. 2019; 19(1):181.

15. Valenzuela PL, Castillo-García A, Morales JS, de la Villa P, Hampel H, Emanuele E, Lista S, Lucia A. Exercise benefits on Alzheimer's disease: state-of-the-science. Ageing Res Rev. 2020; 62:101108.

16. Lamb SE, Sheehan B, Atherton N, Nichols V, Collins H, Mistry D, Dosanjh S, Slowther AM, Khan I, Petrou S, Lall R; DAPA Trial Investigators. Dementia and physical activity (DAPA) trial of moderate to high intensity exercise training for people with dementia: randomised controlled trial. BMJ. 2018; $361: \mathrm{k} 1675$. 
17. Groot C, Hooghiemstra AM, Raijmakers PG, van Berckel BN, Scheltens $P$, Scherder EJ, van der Flier WM, Ossenkoppele R. The effect of physical activity on cognitive function in patients with dementia: a meta-analysis of randomized control trials. Ageing Res Rev. 2016; 25:13-23.

18. Chen $\mathrm{KH}$, Chen HH, Li L, Lin HC, Chen CL, Chen NC. The impact of exercise on patients with dementia: a 2-year follow-up. Medicine (Baltimore). 2020; 99(23):e20597.

19. Meng Q, Lin MS, Tzeng IS. Relationship between exercise and Alzheimer's disease: a narrative literature review. Front Neurosci. 2020; 14:131.

20. Vivar C, Potter MC, van Praag H. All about running: synaptic plasticity, growth factors and adult hippocampal neurogenesis. Curr Top Behav Neurosci. 2013; 15:189-210.

21. Vivar $\mathrm{C}$, Peterson $\mathrm{BD}$, van Praag $\mathrm{H}$. Running rewires the neuronal network of adult-born dentate granule cells. Neuroimage. 2016; 131:29-41.

22. Duzel E, van Praag H, Sendtner M. Can physical exercise in old age improve memory and hippocampal function? Brain. 2016; 139(Pt 3):662-673.

23. Park SS, Park HS, Kim CJ, Kang HS, Kim DH, Baek SS, Kim TW. Physical exercise during exposure to $40-\mathrm{Hz}$ light flicker improves cognitive functions in the 3xTg mouse model of Alzheimer's disease. Alzheimers Res Ther. 2020; 12(1):62.

24. Pinar C, Yau SY, Sharp Z, Shamei A, Fontaine CJ, Meconi AL, Lottenberg CP, Christie BR. Effects of voluntary exercise on cell proliferation and neurogenesis in the dentate gyrus of adult FMR1 knockout mice. Brain Plast. 2018; 4(2):185-195.

25. Zhang X, He Q, Huang T, Zhao N, Liang F, Xu B, Chen X, Li T, Bi J. Treadmill exercise decreases A $\beta$ deposition and counteracts cognitive decline in APP/PS1 Mice, possibly via hippocampal microglia modifications. Front Aging Neurosci. 2019; 11:78.

26. van Praag H, Shubert T, Zhao C, Gage FH. Exercise enhances learning and hippocampal neurogenesis in aged mice. J Neurosci. 2005; 25(38):8680-8685.

27. Siette J, Westbrook RF, Cotman C, Sidhu K, Zhu W, Sachdev P, Valenzuela MJ. Age-specific effects of voluntary exercise on memory and the older brain. Biol Psychiatry. 2013; 73(5):435-442.

28. Snigdha S, de Rivera C, Milgram NW, Cotman CW. Exercise enhances memory consolidation in the aging brain. Front Aging Neurosci. 2014; 6:3.

29. Nithianantharajah J, Hannan AJ. The neurobiology of brain and cognitive reserve: mental and physical activity as modulators of brain disorders. Prog Neurobiol. 2009; 89(4):369-382.

30. Choi SH, Bylykbashi E, Chatila ZK, Lee SW, Pulli B, Clemenson GD, Kim E, Rompala A, Oram MK, Asselin C, Aronson J, Zhang C, Miller SJ, Lesinski A, Chen JW, Kim DY, van Praag H, Spiegelman BM, Gage FH, Tanzi RE. Combined adult neurogenesis and BDNF mimic exercise effects on cognition in an Alzheimer's mouse model. Science. 2018; 361(6406):eaan8821.

31. Xu B, Sun A, He Y, Qian F, Liu L, Chen Y, Luo H. Running-induced memory enhancement correlates with the preservation of thin spines in the hippocampal area CA1 of old C57BL/6 mice. Neurobiol Aging. 2017; 52:106-116.

32. Xu L, Long J, Su Z, Xu B, Lin M, Chen Y, Long D. Restored presynaptic synaptophysin and cholinergic inputs contribute to the protective effects of physical running on spatial memory in aged mice. Neurobiol Dis. 2019; 132:104586.

33. Xu B, Sun A, He Y, Qian F, Xi S, Long D, Chen Y. Loss of thin spines and small synapses contributes to defective hippocampal function in aged mice. Neurobiol Aging. 2018; 71:91-104.

34. Overk CR, Masliah E. Pathogenesis of synaptic degeneration in Alzheimer's disease and Lewy body disease. Biochem Pharmacol. 2014; 88(4):508-516. 
35. O'Dell RS, Mecca AP, Chen MK, Naganawa M, Toyonaga T, Lu Y, Godek TA, Harris JE, Bartlett HH, Banks ER, Kominek VL, Zhao W, Nabulsi NB, Ropchan J, Ye Y, Vander Wyk BC, Huang Y, Arnsten $A F T$, Carson RE, van Dyck $C H$. Association of $A \beta$ deposition and regional synaptic density in early Alzheimer's disease: a PET imaging study with [11C]UCB-J. Alzheimers Res Ther. 2021; 13(1):11.

36. Cleary JP, Walsh DM, Hofmeister JJ, Shankar GM, Kuskowski MA, Selkoe DJ, Ashe KH. Natural oligomers of the amyloid-beta protein specifically disrupt cognitive function. Nat Neurosci. 2005; $8(1): 79-84$.

37. Shankar GM, Bloodgood BL, Townsend M, Walsh DM, Selkoe DJ, Sabatini BL. Natural oligomers of the Alzheimer amyloid-beta protein induce reversible synapse loss by modulating an NMDA-type glutamate receptor-dependent signaling pathway. J Neurosci. 2007; 27(11):2866-2875.

38. Ting JT, Kelley BG, Lambert TJ, Cook DG, Sullivan JM. Amyloid precursor protein overexpression depresses excitatory transmission through both presynaptic and postsynaptic mechanisms. Proc Natl Acad Sci USA. 2007; 104(1):353-358.

39. West MJ. Stereological methods for estimating the total number of neurons and synapses: issues of precision and bias. Trends Neurosci. 1999; 22(2):51-61.

40. Baglietto-Vargas D, Chen Y, Suh D, Ager RR, Rodriguez-Ortiz CJ, Medeiros R, Myczek K, Green KN, Baram TZ, LaFerla FM. Short-term modern life-like stress exacerbates A -pathology and synapse loss in 3xTg-AD mice. J Neurochem. 2015; 134(5):915-926.

41. Bourne JN, Harris KM. Balancing structure and function at hippocampal dendritic spines. Annu Rev Neurosci. 2008; 31:47-67.

42. Sorra KE, Harris KM. Overview on the structure, composition, function, development, and plasticity of hippocampal dendritic spines. Hippocampus. 2000; 10(5):501-511.

43. Harris KM. Structural LTP: from synaptogenesis to regulated synapse enlargement and clustering. Curr Opin Neurobiol. 2020; 63:189-197.

44. Santos-Lozano A, Pareja-Galeano H, Sanchis-Gomar F, Quindós-Rubial M, Fiuza-Luces C, CristiMontero C, Emanuele E, Garatachea N, Lucia A. Physical activity and Alzheimer disease: a protective association. Mayo Clin Proc. 2016; 91(8):999-1020.

45. Mandolesi L, Polverino A, Montuori S, Foti F, Ferraioli G, Sorrentino P, Sorrentino G. Effects of physical exercise on cognitive functioning and wellbeing: biological and psychological nenefits. Front Psychol. 2018; 9:509.

46. López-Ortiz S, Pinto-Fraga J, Valenzuela PL, Martín-Hernández J, Seisdedos MM, García-López O, Toschi N, Di Giuliano F, Garaci F, Mercuri NB, Nisticò R, Emanuele E, Lista S, Lucia A, Santos-Lozano A. Physical exercise and Alzheimer's disease: effects on pathophysiological molecular pathways of the disease. Int J Mol Sci. 2021; 22(6):2897.

47. Niemann C, Godde B, Voelcker-Rehage C. Not only cardiovascular, but also coordinative exercise increases hippocampal volume in older adults. Front Aging Neurosci. 2014; 6:170.

48. Billings LM, Oddo S, Green KN, McGaugh JL, LaFerla FM. Intraneuronal Abeta causes the onset of early Alzheimer's disease-related cognitive deficits in transgenic mice. Neuron. 2005; 45(5):675-688.

49. Webster SJ, Bachstetter AD, Nelson PT, Schmitt FA, Van Eldik LJ. Using mice to model Alzheimer's dementia: an overview of the clinical disease and the preclinical behavioral changes in 10 mouse models. Front Genet. 2014; 5:88.

50. Clinton LK, Billings LM, Green KN, Caccamo A, Ngo J, Oddo S, McGaugh JL, LaFerla FM. Agedependent sexual dimorphism in cognition and stress response in the 3xTg-AD mice. Neurobiol Dis. $2007 ; 28(1): 76-82$. 
51. Cañete T, Blázquez G, Tobeña A, Giménez-Llort L, Fernández-Teruel A. Cognitive and emotional alterations in young Alzheimer's disease (3xTgAD) mice: effects of neonatal handling stimulation and sexual dimorphism. Behav Brain Res. 2015; 281:156-171.

52. Stimmell AC, Baglietto-Vargas D, Moseley SC, Lapointe V, Thompson LM, LaFerla FM, McNaughton BL, Wilber AA. Impaired spatial reorientation in the 3xTg-AD mouse model of Alzheimer's disease. Sci Rep. 2019; 9(1):1311.

53. Bartsch T, Wulff $P$. The hippocampus in aging and disease: from plasticity to vulnerability. Neuroscience. 2015; 309:1-16.

54. Lisman J, Buzsáki G, Eichenbaum H, Nadel L, Ranganath C, Redish AD. Viewpoints: how the hippocampus contributes to memory, navigation and cognition. Nat Neurosci. 2017; 20(11):1434-1447.

55. Moser E, Moser MB, Andersen P. Spatial learning impairment parallels the magnitude of dorsal hippocampal lesions, but is hardly present following ventral lesions. J Neurosci. 1993; 13(9):3916-3925.

56. Bolding KA, Ferbinteanu J, Fox SE, Muller RU. Place cell firing cannot support navigation without intact septal circuits. Hippocampus. 2020; 30(3):175-191.

57. Maras PM, Molet J, Chen Y, Rice C, Ji SG, Solodkin A, Baram TZ. Preferential loss of dorsalhippocampus synapses underlies memory impairments provoked by short, multimodal stress. Mol Psychiatry. 2014; 19(7):811-822.

58. Matsuzaki M, Ellis-Davies GC, Nemoto T, Miyashita $Y$, lino M, Kasai H. Dendritic spine geometry is critical for AMPA receptor expression in hippocampal CA1 pyramidal neurons. Nat Neurosci. 2001; 4(11):1086-1092.

59. Matsuzaki M, Honkura N, Ellis-Davies GC, Kasai H. Structural basis of long-term potentiation in single dendritic spines. Nature. 2004; 429(6993):761-766.

60. Calhoun ME, Jucker M, Martin LJ, Thinakaran G, Price DL, Mouton PR. Comparative evaluation of synaptophysin-based methods for quantification of synapses. J Neurocytol. 1996; 25(12):821-828.

61. McMahon HT, Bolshakov VY, Janz R, Hammer RE, Siegelbaum SA, Südhof TC. Synaptophysin, a major synaptic vesicle protein, is not essential for neurotransmitter release. Proc Natl Acad Sci USA. 1996; 93(10):4760-4764.

62. Masliah E, Mallory M, Alford M, DeTeresa R, Hansen LA, McKeel DW Jr, Morris JC. Altered expression of synaptic proteins occurs early during progression of Alzheimer's disease. Neurology. 2001; 56(1):127-129.

63. Minger SL, Honer WG, Esiri MM, McDonald B, Keene J, Nicoll JA, Carter J, Hope T, Francis PT. Synaptic pathology in prefrontal cortex is present only with severe dementia in Alzheimer disease. $J$ Neuropathol Exp Neurol. 2001; 60(10):929-936.

64. de Wilde MC, Overk CR, Sijben JW, Masliah E. Meta-analysis of synaptic pathology in Alzheimer's disease reveals selective molecular vesicular machinery vulnerability. Alzheimers Dement. 2016; 12(6):633-644.

65. Walsh DM, Selkoe DJ. Deciphering the molecular basis of memory failure in Alzheimer's disease. Neuron. 2004; 44(1):181-193.

66. Oddo S, Caccamo A, Kitazawa M, Tseng BP, LaFerla FM. Amyloid deposition precedes tangle formation in a triple transgenic model of Alzheimer's disease. Neurobiol Aging. 2003; 24(8):1063-1070.

67. Lacor PN, Buniel MC, Chang L, Fernandez SJ, Gong Y, Viola KL, Lambert MP, Velasco PT, Bigio EH, Finch CE, Krafft GA, Klein WL. Synaptic targeting by Alzheimer's-related amyloid beta oligomers. J Neurosci. 2004; 24(45):10191-10200. 
68. Shrestha BR, Vitolo OV, Joshi P, Lordkipanidze T, Shelanski M, Dunaevsky A. Amyloid beta peptide adversely affects spine number and motility in hippocampal neurons. Mol Cell Neurosci. 2006; 33(3):274-282.

69. Tang N, Kepp KP. Abeta42/Abeta40 ratios of Presenilin 1 mutations correlate with clinical onset of Alzheimer's disease. J Alzheimers Dis. 2018; 66(3):939-945.

70. Quartey MO, Nyarko JNK, Maley JM, Barnes JR, Bolanos MAC, Heistad RM, Knudsen KJ, Pennington PR, Buttigieg J, De Carvalho CE, Leary SC, Parsons MP, Mousseau DD. The Abeta(1-38) peptide is a negative regulator of the Abeta(1-42) peptide implicated in Alzheimer disease progression. Sci Rep. $2021 ; 11(1): 431$.

71. Masters CL, Bateman R, Blennow K, Rowe CC, Sperling RA, Cummings JL. Alzheimer's disease. Nat Rev Dis Primers. 2015; 1:15056.

72. Wei W, Nguyen LN, Kessels HW, Hagiwara H, Sisodia S, Malinow R. Amyloid beta from axons and dendrites reduces local spine number and plasticity. Nat Neurosci. 2010; 13(2):190-196. 
Figures and legends:

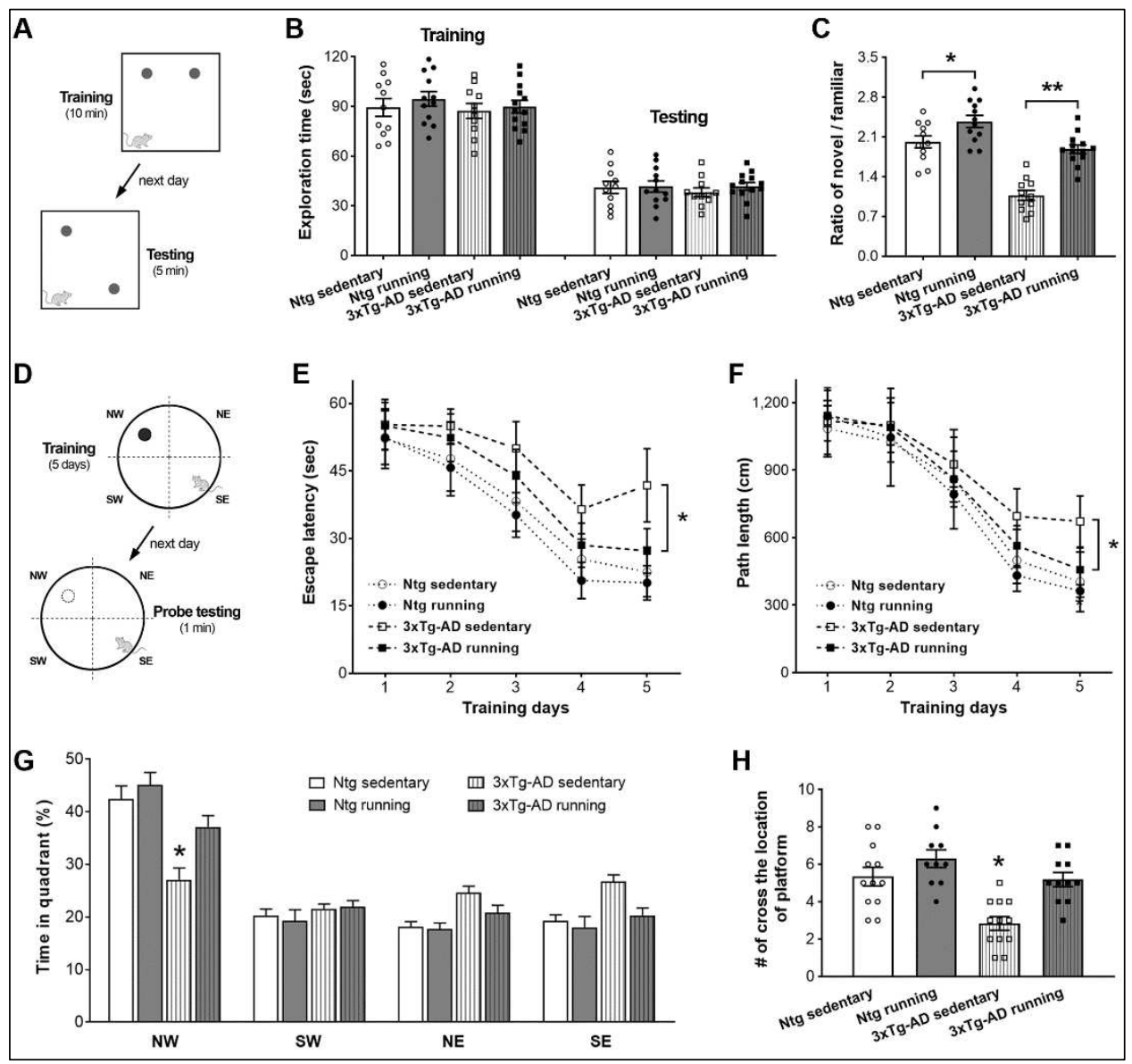

Fig. 1 Voluntary wheel running improves spatial memory.

(A-C) Spatial memory was detected via a novel object location task. (A) After 5 days' habituation, mice received $10 \mathrm{~min}$ of training with two identical objects located at two different locations. The testing (5 $\mathrm{min}$ ) was performed next day during which one object was moved to a novel location. The ratio of novel object vs. familiar object was used as index to represent spatial memory. (B) No differences in exploration time among the four groups during training (two-way ANOVA, genotype: $F_{[1,43]}=0.56, P=0.46$; running: $F_{[1,43]}$ $=0.73, P=0.40$ ) and testing (genotype $\times$ running: $F_{[1,43]}=0.22$ and $0.46, P=0.64$ and 0.50 , respectively), $\mathrm{n}=11-13$ mice. $(\mathbf{C})$ Runners had higher novel/familiar ratio compared with controls with same gene background (Tukey's post hoc test, ${ }^{*} P<0.05$ and ${ }^{* *} P<0.01$ ).

(D-H) Memory performance in a water maze. (D) Mice were trained for 5 days to explore a hidden platform located in north-west (NW) quadrant, followed by a spatial probe testing during which the platform was removed. (E, F) Escape latency and path length to find the platform over training days. On day 5 and day 4, 3xTg-AD runners spent less time (two-way ANOVA, day 5: $F_{[1,41]}=25.69, P<0.0001$; day 4: $F_{[1,41]}=$ 15.86, $P=0.0003$; Tukey's post hoc test, ${ }^{*} P<0.05$ ) and swam short distance (day 5: $F_{[1,41]}=14.96, P=$ 0.0004; day 4: $F_{[1,41]}=8.04, P=0.0071$; post hoc test, ${ }^{*} P<0.05$ ) to reach the hidden-platform compared with 3xTg-AD sedentary mice, $n=10-12$ mice. $(\mathbf{G}, \mathbf{H})$ During the probe testing, 3xTg-AD runners and Ntg mice (both runners and controls) preferred exploring in NW platform quadrant rather than in other quadrants (three-way ANOVA, $F_{[3,164]}=115.9, P<0.0001$; post hoc test, $\left.P<0.05\right)$, whereas $3 \times \mathrm{Tg}$-AD sedentary controls explored all quadrants equally $(P>0.05)$. In the NW quadrant, 3xTg-AD runners $(\mathrm{n}=11)$ spent more time (in \%) (two-way ANOVA, $F_{[1,41]}=10.72, P=0.002$; post hoc test, ${ }^{*} P<0.05$ ) and crossed the location of removed platform more frequently $\left(F_{[1,41]}=14.64, P=0.0004\right.$; post hoc test, $\left.{ }^{*} P<0.05\right)$ compared with $3 x \operatorname{Tg}-A D$ sedentary controls $(n=12)$. 


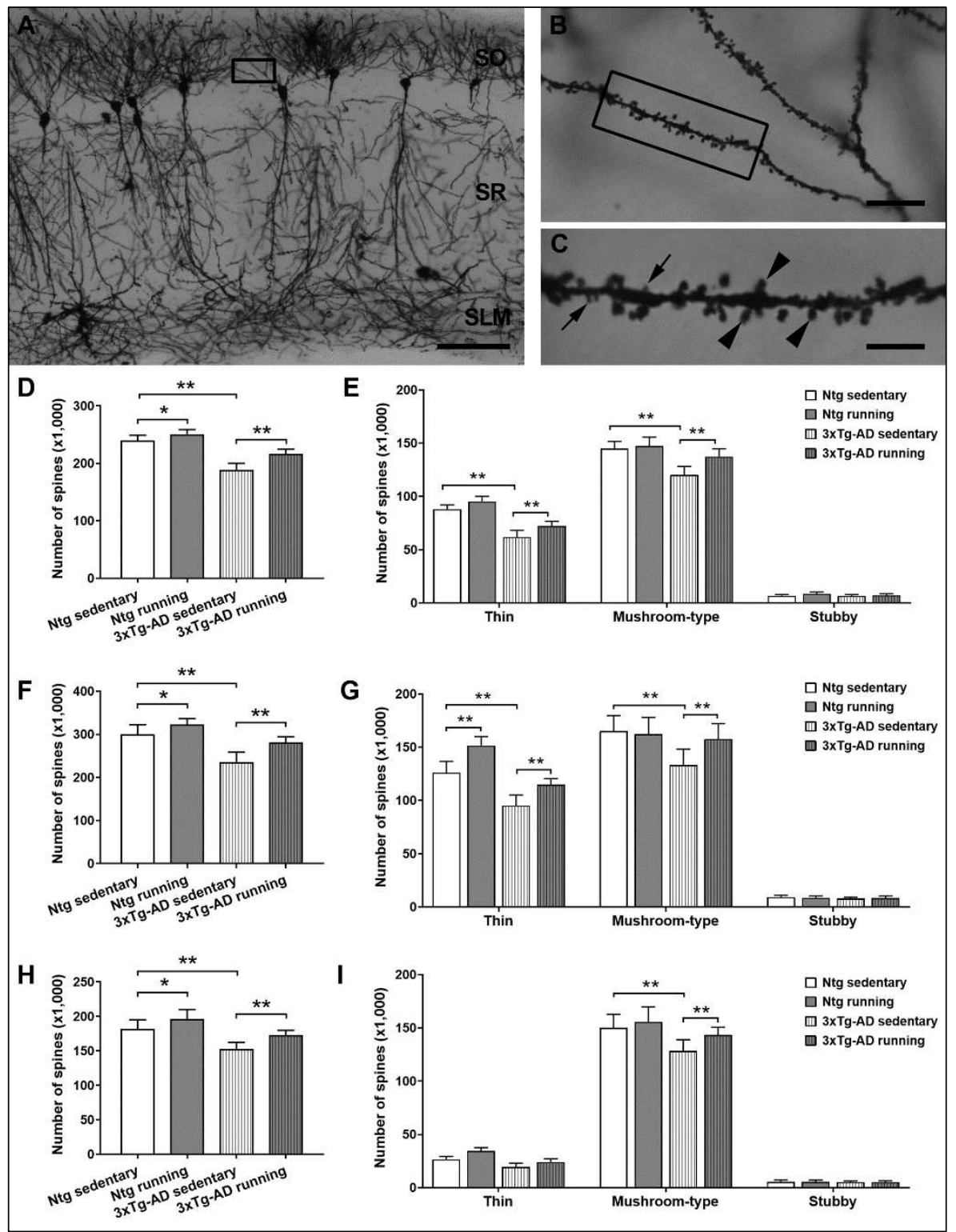

Fig. 2 The effects of physical running on dendritic spines in area CA1 of dorsal hippocampus.

(A-C) Representative images from a 7-month-old 3xTg-AD runner to clarify the location and subcellular domains of Golgi-stained cells in area CA1. Dendritic segments in B were taken from boxed area in the stratum oriens (SO) in $\mathbf{A}$. Boxed segment in $\mathbf{B}$ was further magnified in $\mathbf{C}$ to show thin spines (arrows) and mushroom-type spines (arrowheads). Stubby spines were occasionally observed, but not in this image. (DI) Stereological quantitative analyses showed that increased number of spines was apparent in $3 \times T g-A D$ runners and Ntg runners in SO, SR, and SLM when compared with age-matched 3xTg-AD and Ntg sedentary controls, respectively (Tukey's post hoc test, $\left.{ }^{* \star} P<0.01\right)(\mathbf{D}, \mathbf{F}, \mathbf{H})$. Notably, both thin and mushroom-type spines were protected in the 3xTg-AD running mice compared with 3xTg-AD sedentary controls. However, only thin spines were affected in Ntg-runners compared with Ntg sedentary controls (E, G, I). $\mathrm{n}=11-13$ mice per group, ${ }^{*} P<0.05,{ }^{* *} P<0.01$. SR: stratum radiatum; SLM: stratum lacunosummoleculare. Scale bars: $100 \mu \mathrm{m}$ in $\mathbf{A}, 10 \mu \mathrm{m}$ in $\mathbf{B}$, and $2 \mu \mathrm{m}$ in $\mathbf{C}$. 

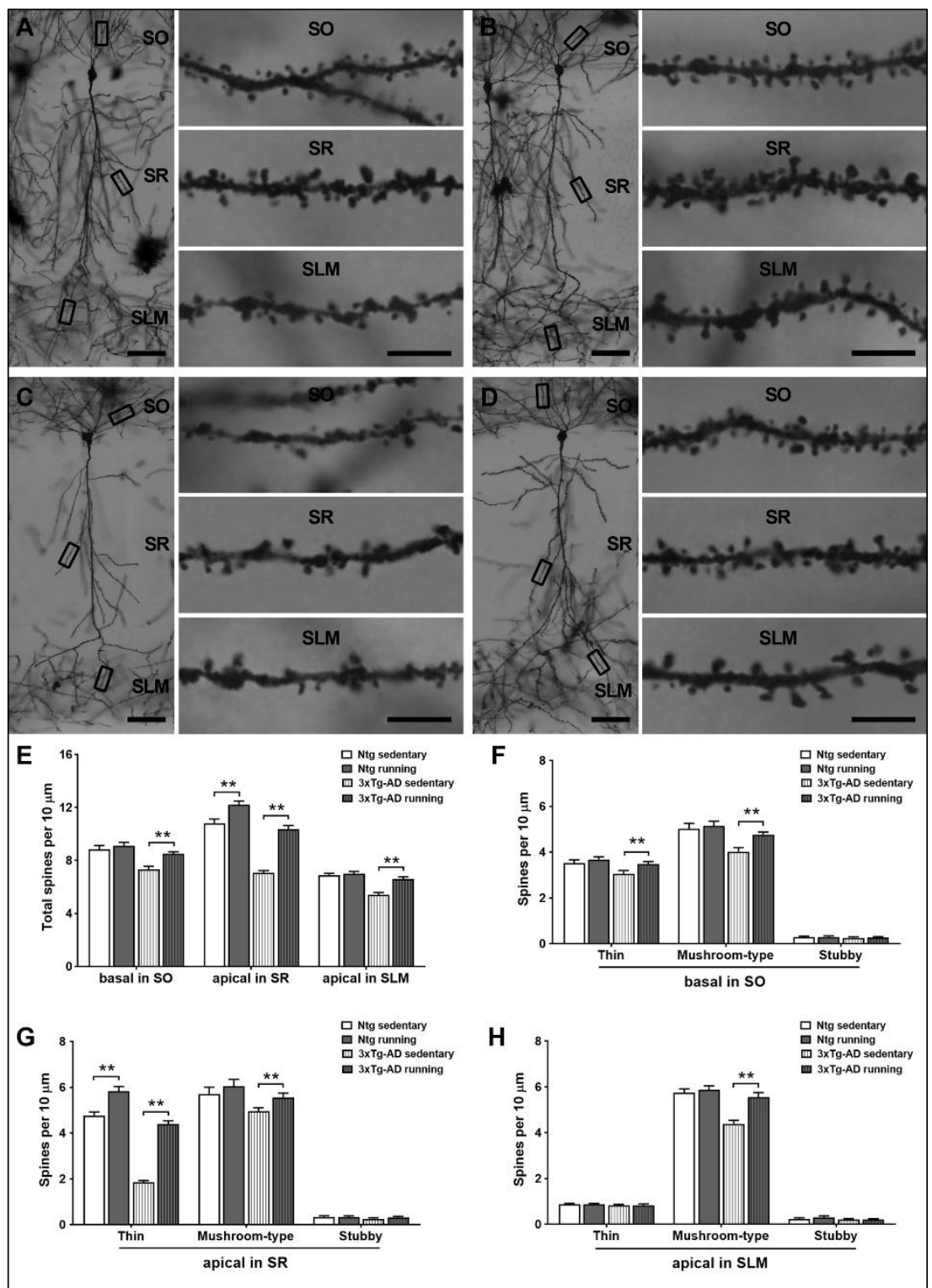

Fig. 3 Physical running protects against the loss of spines on CA1 pyramidal cells in 3xTg-AD mice.

(A-D) Representative CA1 pyramidal cells in Ntg sedentary (A), Ntg running (B), 3xTg-AD sedentary (C), and 3xTg-AD running (D) mice at 7 months of age. The boxed basal and apical dendritic segments were magnified to show thin and mushroom-type spines. Less spines were observed on basal and apical dendrites in 3xTg-AD sedentary mice (C) compared with Ntg sedentary mice (A). Increased number of spines was observed in 3xTg-AD runner (D) versus 3xTg-AD sedentary control (C). SO: stratum oriens; SR: stratum radiatum; SLM: stratum lacunosum-moleculare. Scale bars: $50 \mu \mathrm{m}$ in low magnification images and $5 \mu \mathrm{m}$ in high magnification images.

(E-H) Analyses of dendritic spines on individual CA1 pyramidal cells. (E) Loss of spines on basal and apical dendrites was apparent in 3xTg-AD sedentary mice versus Ntg sedentary mice $\left(F_{[1,129]}=144.8, P<0.0001\right.$; post hoc test, $P<0.01$, not marked in the graph). Running affected spines on either basal dendrites or apical dendrites in 3xTg-AD mice, whereas the effect of running was observed on apical dendrites in Ntg mice $\left({ }^{* *} P<0.01\right)$. $(\mathbf{F}-\mathbf{H})$ Both thin and mushroom-type spines on basal and apical dendrites were protected in 3xTg-AD runners compared with 3xTg-AD sedentary controls $\left({ }^{* *} P<0.01\right)$. Only thin spines on apical dendrites in SR were affected by running in Ntg mice. Spine density is expressed as the number of spines per $10 \mu \mathrm{m}$ dendritic segment. Three-way ANOVA was performed with genotype (Ntg vs. 3xTg-AD), running, and spine type/dendritic branch as factors, followed by Tukey's or Bonferroni's post hoc test. The values represent the mean \pm S.E.M. $(n=11-13)$. 

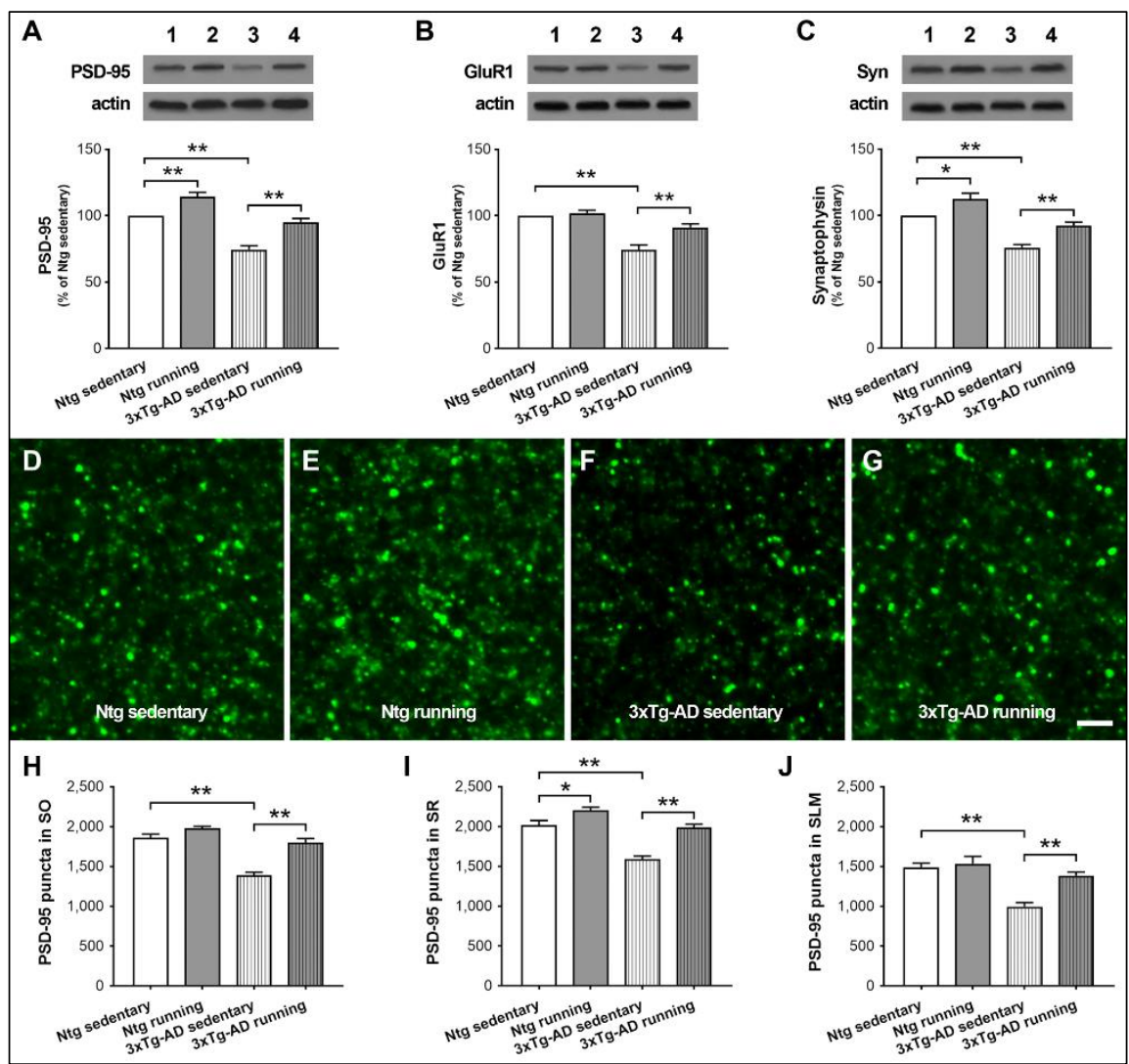

Fig. 4 Physical running alleviates synaptic deficits in dorsal hippocampus of 3xTg-AD mice.

(A-C) The levels of synaptic proteins including PSD-95, GluR1, and synaptophysin in hippocampal CA1. Representative bands from Ntg sedentary (1), Ntg running (2), 3xTg-AD sedentary (3), and 3xTg-AD running (4) mice at 7 months of age. The optical densities of bands corresponding to PSD-95, GluR1, and synaptophysin were normalized to respective protein levels of actin and expressed as \% of Ntg sedentary controls. Whereas running wheel for 5 months upregulated the expressions of PSD-95 and synaptophysin, but not GluR1 in Ntg mice, running protected against the loss of all three measured proteins in 3xTg-AD mice (data were expressed as mean $\pm \mathrm{SEM}$, ${ }^{* \star} P<0.01,{ }^{*} P<0.05, \mathrm{n}=6$ mice per group).

(D-J) Effects of running on PSD-95-ir puncta in area CA1. Representative confocal z-stack images in SR from Ntg sedentary (D), Ntg running (E), 3xTg-AD sedentary (F), and 3xTg-AD running (G) mice. Quantitative analysis of PSD-95-ir puncta $(\mathbf{H}-\mathbf{J})$. Three-way ANOVA analysis (genotype $\times$ running $\times$ region) showed a significant genotype effect $\left(F_{[1,60]}=121.2, P<0.0001\right)$ and running effect $\left(F_{[1,60]}=77.64, P<\right.$ $0.0001)$ with genotype-by-running interaction $\left(F_{[1,60]}=22.70, P<0.0001\right)$. Tukey's post hoc test, ${ }^{* *} P<0.01$, ${ }^{*} P<0.05$. SO: stratum oriens; SR: stratum radiatum; SLM: stratum lacunosum-moleculare. Scale bars: 4 $\mu \mathrm{m}$ in $\mathbf{D}-\mathbf{G}$. 


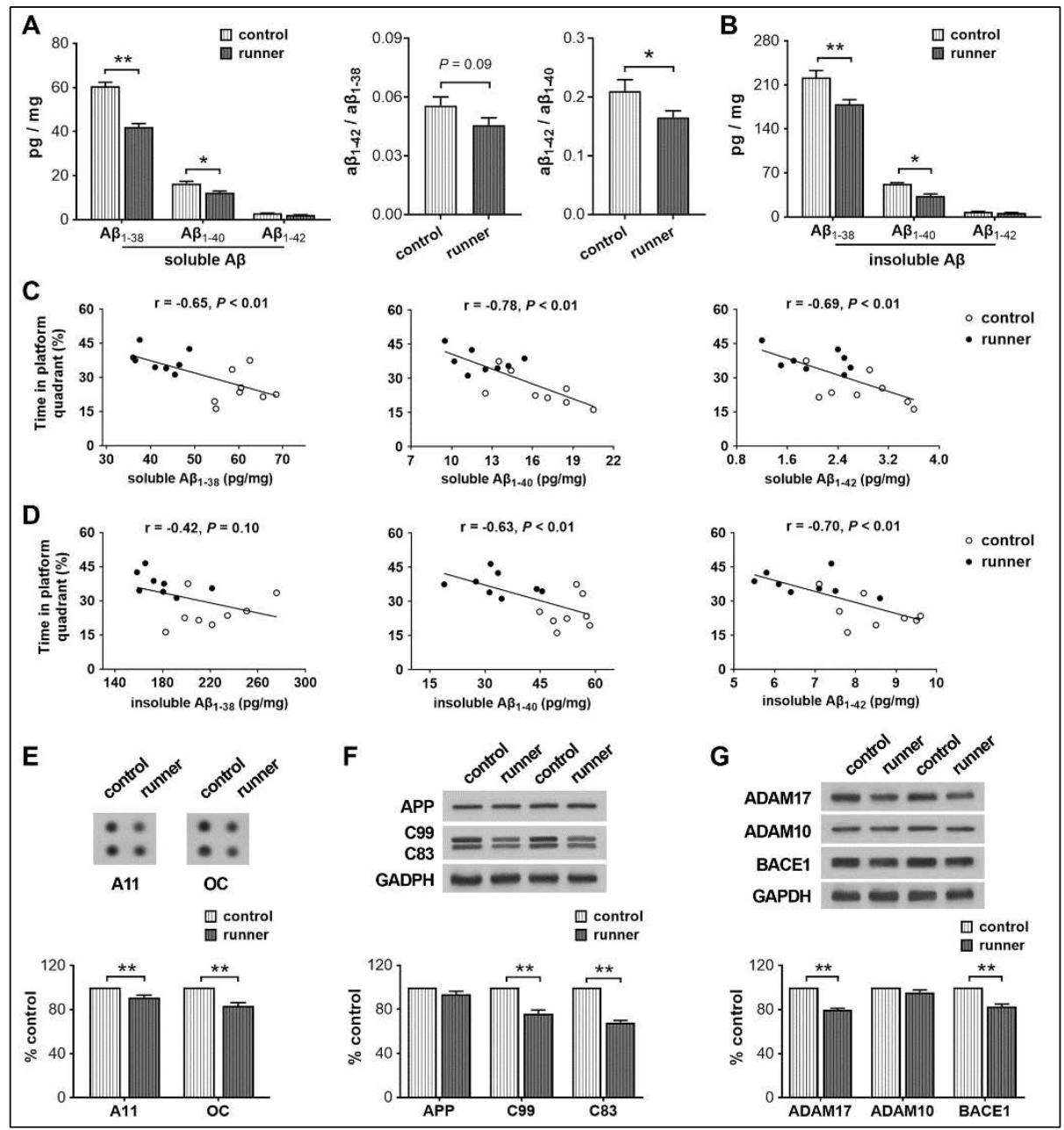

Fig. 5 Effects of physical running on $A \beta$ pathology in 3xTg-AD mice.

(A, B) Voluntary running for 5 months downregulated the levels of $A \beta$ peptides including soluble and insoluble fractions in area $\mathrm{CA} 1$ of dorsal hippocampus. The running mice had decreased ratio of soluble $A \beta_{1-42} /$ soluble $A \beta_{1-40}$ compared with the sedentary mice $\left({ }^{\star} P<0.05\right)$.

(C, D) Correlation between the levels of $A \beta$ peptides and spatial memory performance. Negative correlations were observed between the $\%$ time spent in the platform quadrant and soluble $A \beta$ peptides (Pearson $r=-0.65,-0.78$, and -0.69 for $A \beta_{1-38}, A \beta_{1-40}$, and $A \beta_{1-42}$, respectively, all $\left.P<0.01\right)$ (C). The $\%$ time in the platform quadrant negatively correlated with insoluble $A \beta$ peptides including $A \beta_{1-40}$ and $A \beta_{1-42}(r=-$ 0.63 and -0.70 , respectively, $P<0.01)$, but not $A \beta_{1-38}(r=-0.42, P=0.1)$ (D).

(E) Decreased $A \beta$-oligomers including $A B 40$ oligomers (A11) and amyloid fibril (OC) in 3xTg-AD running mice compared with sedentary controls. (F) The levels of APP holoprotein and APP C-terminal fragments (C99 and C83) in CA1. Representative bands from 3xTg-AD sedentary controls and 3xTg-AD runners. The optical densities of bands corresponding to APP, C99, and C83 were normalized to respective protein levels of GAPDH and expressed as \% of sedentary controls. No difference in APP, but downregulation in C99 and $\mathrm{C} 83$ in 3xTg-AD runners vs. sedentary controls. (G) Analyses of $\alpha$-secretases ADAM-17 and ADAM10 and $\beta$-secretase BACE1 in tissues of area CA1. The optical densities of bands were normalized and expressed as $\%$ of controls. ${ }^{*} P<0.05,{ }^{* *} P<0.01$. 